Recenzje i omówienia

Zbigniew Libera

Uniwersytet Jagielloński e-mail: zbigniew.libera@uj.edu.pl

\title{
Recenzja książki Elżbiety Jodłowskiej i Mirosława Mąki, Pishtaco. Fenomen symbolizacji traumy kulturowej w społecznościach andyjskich, Wydawnictwo Nomos, Kraków 2016, $243 \mathrm{~s}$.
}

Elżbieta Jodłowska jest absolwentką Amerykanistyki i Studiów Polonijnych Uniwersytetu Jagiellońskiego oraz Akademii Sztuk Pięknych w Krakowie, autorką prac $\mathrm{z}$ etnografii Polski oraz jedynego w Polsce artykułu na temat pishtaco. Mirosław Mąka ukończył studia z etnologii w Krakowie, jest autorem artykułów z etnologii Andów, książek z zakresu historii etnografii i fotografii oraz historii kultury.

Od ośmiu lat prowadzą oni badania etnograficzne w północnej części Andów. Te łączą z uprawianiem alpinizmu. W wysokogórskiej części Andów, w rejonie Ancash, zyskali status padrinos, rodziców ślubnych w znanej tu i szanowanej rodzinie, co znacznie ułatwiło tym gringos badania etnograficzne (bardzo rzadko zdarza się w Peru, żeby gringos byli wybierani na padrinos indiańskiej pary). Jednak nawet ten wyjątkowy status nie zapewnił autorom omawianej książki łatwego i prostego dostępu do miejscowych wierzeń, zwłaszcza jeśli ich pytania dotyczyły postaci tak niebezpiecznej i realnej dla Indian w Andach, jak pishtaco. Mirosław Mąka z powodu wyglądu (biały i brodaty mężczyzna) oraz zachowań (np. rozdawał noże w prezencie) był podejrzewany o bycie pishtaco podczas wypraw alpinistycznych. Autorzy omawianej książki doświadczali swoistej wszechobecności pishtaco w życiu andyjskich Indian. Dotychczasowe badania etnograficzne postanowili skierować na zgromadzenie wszelkich doniesień naukowych, literackich, internetowych, i tym podobnych, na temat tej postaci. W tych znajdowali godne uwagi interpretacje fragmentaryczne, lecz żadne opracowanie naukowe nie 
dostarczyło im wyjaśnień całościowych fenomenu. Tak powstała książka E. Jodłowskiej i M. Mąki - na podstawie przede wszystkim prac peruwiańskich uczonych i literatów, w której duże znaczenie mają też publikacje polskie: głównie Jana Szemińskiego i Aleksandra Posern-Zielińskiego. Doświadczenia własne autorów są rzadko jawnie przywoływane w książce. Ta jednak w całości jest świadectwem dużej znajomości wielu problemów historii i kultury Peru, życia Indian Keczua w północnych Andach. Dodatek Pishtaco w Cordillera Blanca jest sprawozdaniem z badań terenowych wśród Indian Keczua, przeprowadzonych na początku 2016 roku, dołączonym do tekstu książki, gdy ten był już opracowywany redakcyjnie. Ten daje wiedzę o sposobach i trudnościach zdobywania informacji, dostarcza wiedzy o specyfice regionalnych wierzeń, różnicach w relacjach Indian i osób $\mathrm{z}$ miejscowych środowisk naukowo-kulturalnych na temat pishtaco, poświadcza, jak te opowieści wierzeniowe są otwarte na najnowsze zjawiska i procesy cywilizacyjne. Dodatek ma do pewnego stopnia wartość sprawdzającą interpretacji wyłożonych w książce.

Omawiana książka składa się z szesnastu rozdziałów. Te zostały uporządkowane (trudno tu wskazać wyraźne granice) tak, że siedem pierwszych dostarcza systemowego przedstawienia problemu - jednocześnie z perspektywy antropologii i historiografii, po części psychologii społecznej i socjologii - a w następnych przeważają interpretacje fenomenologiczno-hermeneutyczne charakterystycznych elementów z „modelowego" portretu pishtaco. Autorzy wskazują na to wyraźnie w Zakończeniu: „Dopiero droga od «modelu» do szczegółu ujawnia jego indywidualność oraz różnorodność związków z szeroko rozumianym podłożem kulturowym. I dopiero wtedy zaczyna być naprawdę ciekawie!” (s. 200). Tak rzeczywiście jest. Treści kolejnych części książki zaskakują odkrywanymi związkami opowieści wierzeniowych z niemal wszystkimi sferami życia andyjskich Indian, zdumiewa paradoksalna trwałość i elastyczność tych tekstów. Metody prezentacji danych etnograficznych i historycznych, wraz z umiejętnością opowiadania i pisania, powodują, że tę etnologiczną pracę czyta się miejscami niemal jak powieść detektywistyczną.

Książkę rozpoczyna rozdział 1: Zwięzła charakterystyka pishtaco - szkic etnograficzny postaci z wierzeń Indian w południowym Ekwadorze, Peru, północnej Boliwii - której nie da się przyporządkować znanym kategoriom istot mitologii i religii, opis swoistych jej wcieleń (lokalnych nazw, zmiennych cech, zachowań i czynności), wielkich zdolności do semantycznych transformacji w lokalnych tradycjach, w historii - od pierwszych relacji z XVI wieku do najnowszych jej obrazów w popkulturze. Mimo nadzwyczaj licznych i zróżnicowanych tekstów etnografii i historii, stale powtarzają się układy cech: pisthaco to mężczyzna, obcy, biały, wysoki, $\mathrm{z}$ brodą, w habicie lub na przykład w mundurze, którego podstawowym zajęciem jest polowanie na Indian i zdobywanie tłuszczu z martwych ciał do wyrobu maści i leków albo odlewanych dzwonów kościelnych, smarowania mechanizmów młynów, urządzeń w kopalniach i tak dalej. 
W tym omówieniu materiałów historii i etnografii znajdujemy dobrze znane rozróżnienia strukturalnej semiotyki: wariant - inwariant, system - tekst, tekst - kontekst. Tym zapowiedziano rozdział 2: Zarys metodologii, który wiąże się z celami pracy: całościowym ujęciem problemu z perspektywy antropologii kulturowej, w której dominujące znaczenie mają wybrane elementy analizy strukturalnej Claude’a Lévi-Straussa oraz historiografii Ferdynanda Braudela, bo te są nadal, według oceny autorów, skutecznymi narzędziami interpretacji społeczeństw homogenicznych, do jakich należą Indianie Keczua, przydatnymi w przypadku andyjskich kultur, „z jednej strony głęboko czerpiących z tysiącleci tradycji, z drugiej zaś poddanych potężnej fali akulturacji; kompatybilność refleksji etologicznej i historycznej jawi się jako warunek priorytetowy" (s. 15). Konsekwencją porządkowania faktów do „struktur długiego trwania” albo „koniunktur” czy „zdarzeń”, określania systemowości i mechanizmów strukturalnych transformacji wierzeń $\mathrm{w}$ okresie niemal pięciu wieków jest zabieg zestawiania faktów etnograficznych i historycznych, pomieszanie chronologii, „jeśli w obu dostrzegamy wspólny mechanizm myślenia lub tożsamości genezy mitycznej" (s. 15). Porządkowanie obszaru badań, wychwycenie wewnętrznych relacji i regularności należy do pierwszych zadań autorów. Z nimi kończą się granice stosowalności analiz strukturalnych. Kolejnym ich celem było uchwycenie mechanizmów i procesów symbolizacji, semantyki wybranych elementów pishtaco. Systemowa perspektywa została uzupełniona dyskursami fenomenologii i hermeneutyki. Autorzy podkreślają, że nie mają zamiaru rygorystycznie przestrzegać wskazanych metod interpretacji; wybierają z nich te elementy, które uznają za użyteczne dla stawianych celów.

Do pewnego stopnia uwagi metodologiczne są kontynuowane $\mathrm{w}$ rozdziale 3: Materiały źródłowe w twórczości Mario Vargasa Llosy i Jose Marii Arguedasa. Ten rozdział dostarcza „usprawiedliwienia” częstego przywoływania odpowiednich fragmentów książek peruwiańskich pisarzy, traktowania ich jako źródeł na równych prawach $\mathrm{z}$ materiałami historii i etnografii, jako takich, które zawierają sugestie interpretacyjne do „zagadki pishtaco", są literacko wyrażonymi syntezami wielu tekstów znanych etnografom i historykom, skumulowanymi prawdami na temat pishtaco. Arguedas był z wykształcenia etnologiem. On i Llosa zawarli w swych książkach głęboką i wszechstronną znajomość życia Indian w Peru. Z punktu widzenia badaczy kultury Andów - twierdzą autorzy - niektóre ich książki są pracami etnologicznymi.

Ważną częścią omawianej pracy jest rozdział 4: Konotacje kulturowe ludzkiego tłuszczu w kulturach andyjskich. Tu została sformułowana hipoteza, na której opiera się dalsza część książki. W tych kulturach doszło do przesunięcia mitologiczno-symbolicznych znaczeń z krwi na tłuszcz. Z powodu warunków życia Indian w Andach (predyspozycje do obfitego odkładania tkanki tłuszczowej mają ludzie w strefach wysokogórskich i zimnych) to tłuszcz, a nie krew, ma pozytywne konotacje, symbolizuje zdrowie, siłę, potencję, władzę i tak dalej. Szczególna 
dyssymetria tłuszczu-krwi, łączenie z krwią stabilnego czynnika życia, z tłuszczem zaś - aktywnego potencjału jego przekazywania, ma wyjaśniać to, że pishtaco nigdy nie był postacią, która przypominałaby europejskiego wampira, ale przecież główną racją jego istnienia było zawsze pozyskiwanie tłuszczu z ciał młodych Indian - „nie tylko fizyczno-materialnego komponentu ciała, lecz przede wszystkim potencjału życiowego w sensie dosłownym i symbolicznym" (s. 29). Potwierdzenia tej hipotezy znajdują autorzy w językach keczua i ajmara, w prekolumbijskich mitologiach, rytuałach ofiarniczych, następnie w relacjach andyjskich Indian o pishtaco. W Zakończeniu napisali oni: „Sądzimy, że nasza hipoteza na temat dualistycznego i dyssymetrycznego związku krwi i tłuszczu może stanowić punkt wyjścia do zrozumienia i wytłumaczenia genezy postrzegania oraz różnych form użycia tłuszczu ludzkiego na tym obszarze kulturowym” (s. 201-202).

Rozdział 5: Treści semantyczne nazwy pishtaco oraz źródła i prefiguracje postaci dotyczy przede wszystkim problemu, czy ta postać i postaci pokrewne $\mathrm{w}$ wierzeniach andyjskich Indian, które zajmują się zarzynaniem, krojeniem, ćwiartowaniem, pozyskiwaniem tłuszczu $\mathrm{z}$ ciał zabitych (te zajęcia zostały odzwierciedlone w znaczeniach etymologicznych i semantycznych ich nazw), wywodzą się z prekolumbijskich mitologii i religii (bo np. jedną z charakterystycznych czynności pishtaco jest obcinanie głów i trzymanie ich za włosy, co jest znane z rodzimych historii kultur); czy też pishtaco został „przywieziony jako gotowy produkt” ze Starego Świata (bo np. w kulturze ludowej Hiszpanii sacamanteca wysysał tłuszcz, lecz ten miał tu całkiem inne znaczenia symboliczne). Autorzy opowiedzieli się za ustaleniami, że mit pishtaco został skonstruowany w Nowym Świecie w XVI wieku, i na jego powstanie miały wpływ elementy rodzime oraz przejęte od Hiszpanów; historia tego mitu odpowiada historii konkwisty i późniejszych wieków Peru, jest skutkiem symbolizacji traumy kulturowej w społeczeństwach andyjskich. Takie dociekania wymagały od autorów porównywania treści wierzeń ludowych w Peru i na Półwyspie Iberyjskim, dały możliwość zwrócenia uwagi na to, że w takich porównawczych badaniach nie należy ograniczać się do jednokierunkowych i jednorazowych transmisji kulturowych z Hiszpanii do Peru (jak o tym powtarza się w odpowiednich opracowaniach), lecz trzeba brać pod uwagę kierunek przeciwny, wskutek czego między innymi mit pishtaco mógł ulegać przeformułowaniu w kulturze ludowej Hiszpanii i taki wracać do Nowego Świata.

Książkę czyta się z niesłabnącym zainteresowaniem. Dzieje się tak także dlatego, że omówione szczegółowe problemy mają swe rozwinięcie w następnych rozdziałach, w których są one komentowane z innych niż wcześniej perspektyw. W rozdziale 6: Trauma kulturowa a narodziny pishtaco początki tworzenia się tego mitu w XVI-XVII wieku zostały omówione w pespektywy psychologii społecznej i fenomenologii symboli. W sytuacji destrukcji fizycznego i społecznego świata, traumy kulturowej andyjskich Indian rozpoczęły się procesy symbolizacji przybyszów „z morza”, obcych i wrogów, zbiorowych lęków. Te doświadczenia znalazły symboliczne wyrażenie w obrazie pishtaco. Wzmacniały je pogłoski, które mają 
swe poświadczenia $\mathrm{w}$ źródłach z drugiej połowy XVI i pierwszej połowy XVII wieku, że Hiszpanie wytwarzają leki i maści na rany i owrzodzenia z tłuszczu zabijanych Indian, że przybyli tu specjalnie po tłuszcz od młodych i grubych mężczyzn - nie od zmarłych, ale zabijanych.

E. Jodłowska i M. Mąka zwracają uwagę na nawet najdrobniejsze elementy obrazu pishtaco. Dzięki temu, że „zwracają wręcz maniakalną uwagę na szczegóły" (fraza Lévi-Straussa), potrafią rozpoznać detale tego mitu w widowiskach teatru ludowego, ceremoniach religijnych, w kościelnych obrazach. Świetnym tego przykładem jest rozdział 7: Meandry synkretyzmu - Nino Nakaq z Ayacucho. Ten rozdział (inspirowany pracami J. Szemińskiego) jest także pokazaniem tego, jak połączenie analiz antropologicznych i historycznych (to przypomina też wysiłki egzegezy biblijnej) pozwala na wskazanie czasu powstania lokalnych wariantów mitu na podstawie zachowanych opisów pewnego widowiska z XIX wieku, znajomości czasu powstania Kościoła, okresu działalności zakonów i tak dalej.

Odwoływanie się do kontekstów społecznych czy symbolicznych jest koniecznością, jeśli dąży się do wykazania, jak w tym wypadku, że rozpatrywane mity mają spójną ideową strukturę, łączą one „struktury długiego trwania” z „koniunkturalnymi zdolnościami" do adaptowania nowych znaków historii (bez wypierania znaków dotychczasowych), że każdy element tych przekazów jest znaczący i motywowany. Uwzględnianie licznych kontekstów historii i kultury dostarcza klucza do zrozumienia tekstów o pishtaco, a jednocześnie wgląd w rozmaite problemy, między innymi społeczne, religijne, polityczne, cywilizacyjne, andyjskich Indian od XVI wieku aż po lata ostatnie.

Nie jest możliwe pełne omówienie dalszych części książki, tych, gdzie „zaczyna być naprawdę ciekawie". Wskażę tylko najogólniej zakres spraw omawianych przez E. Jodłowską i M. Mąkę. W rozdziale 8: Tłuszcz Indian jako spiritus movens - od dzwonów do laptopów znajdują się wyjaśnienia sensu dodawania tłuszczu zabitych Indian do dzwonów kościelnych, żeby brzmiały one piękniej i donioślej (co wymagało „uzgodnienia” symboliki tłuszczu z symboliką dzwonów, dźwięków, muzyki), w coraz nowszych przekazach: do mechanizmów młynów, urządzeń w kopalniach, fabrykach, w samochodach, samolotach, komputerach, iPodach... To kolejny raz dowodzi, że pishtaco "ma się zawsze dobrze”, ciągle wyraża obcy i wrogi świat, instytucje przemocy i wyzysku, to samo poczucie skrzywdzenia, poniżenia i lęku Indian. Te mity obcego i nieludzkiego świata zostały omówione także w rozdziale 9: Zły czas i złe miejsce, czyli czasoprzestrzeń pishtaco. W czasie i przestrzeni, w których zamiera aktywność życiowa „swoich”, działa on: po zmierzchu, w nocy, w miejscach ciemnych i zimnych (w kopalniach, grotach, szczelinach skalnych itp.), w ogóle przestrzeni poza ekumeną Indian (więc ich siedliskiem jest Lima czy costa). E. Jodłowska i M. Mąka nie ignorują wyjątkowych relacji: pishtaco działa w biały dzień - mogą one świadczyć o tym, że Indianie mają poczucie wzrostu siły wroga. $Z$ jego czasoprzestrzenią zgadzają się wygląd i zachowania przypominające obcych, nieludzi: pishtaco jest śmiertelnie 
blady, nie mówi lub mówi niezrozumiałym językiem, nie żuje koki, jest kanibalem (z punktu widzenia Indian), łamie podstawowe tabu... O jego naturze informują nie tylko same przekazy folklorystyczne - zwracają uwagę autorzy - ale także działania magiczno-rytualne, same tylko środki obronne (woda w naczyniach drewnianych sól, czosnek, ekskrementy itd.). Rozdział 10: Pishtaco w szatach zakonnika pokazuje, że te wizualizacje są tak dokładne, że można je identyfikować z konkretnymi zakonami. Wzorcowym tego przykładem są relacje z Cuzco od XVII do XX wieku, które w najdrobniejszych szczegółach - pishtaco poluje na Indian w habicie, $\mathrm{z}$ kapturem zasłaniającym twarz, jest biały, brodaty, wysoki, włóczy się po okolicy z dzwonkiem i/lub książką (brewiarzem), naczyniem z proszkiem do usypiania swych ofiar - odnoszą się do wyglądu, zachowań, reguł, działalności (prowadzenie szpitali i wyrabianie leków) Braci Betlejemskich. $\mathrm{W}$ wierzeniach andyjskich Indian dominują wyobrażenia pishtaco jako zakonnika czy księdza, dość częste są jego wizualizacje jako żołnierza. Denotują one specyficzny stosunek do Kościoła i wojska jako instytucji władzy, przemocy, strachu i wyzysku. Rozdział 11: Pishtaco umundurowany nawiązuje do ubiorów, ale też do okrucieństw żołnierzy Peru czy Boliwii XIX-XX wieku (brakuje opisów tej postaci przypominających żołnierzy z XVI-XVII wieku), w ostatnich czasach do wyglądu i uzbrojenia partyzantów Świetlistego Szlaku (powiązanie tego z mitem pishtaco należy do jednych z najbardziej intrygujących miejsc książki). Pishtaco ma mnóstwo wcieleń. Za każdym razem jest mitologiczno-symboliczną figurą obcych i wrogów, w której utrwalały się doświadczenia Indian wywołane konkwistą, kolonizacją, współczesnymi problemami Peru. Wykorzystywane w ramach tej figury elementy ze starych mitologii, na przykład dziki wygląd, rude brody, twarze brudne i pokryte zmarszczkami, wrzodami, krostami czy bąblami, odsyłają do hiszpańskich najeźdźców, którzy powodowali choroby i nieszczęścia. To najkrótsze i najprostsze przedstawienie rozdziału 12: Odrażające oblicze pisthaco jako symbolizacja choroby. Rozdział 13: Pishtaco $z$ książk - lekarze, inżynierowie, naukowcy w szczególny sposób pokazuje, że wystarczy jeden atrybut obcości, żeby zostać posądzonym o zainteresowanie tłuszczem Indian. Wśród niepiśmiennych społeczności samo czytanie (np. w autobusie) wzbudza podejrzenia. Lęk i agresja wzrastają szczególnie wtedy, gdy jedna taka cecha łączy się z innymi, gdy obcy, tacy jak antropolodzy, archeolodzy, geodeci, lekarze, misjonarze, turyści, włóczą się po nie swoich okolicach, w niezrozumiałych celach przepytują ludzi, mierzą, liczą, piszą... Prawdziwym objawieniem talentów autorów są - wymienię tylko tytuły rozdziałów, bez omówienia ich treści - rozdział 14: Miejskie wcielenia pishtaco - ewolucja symbolu i rozdział 15: „Ciemność” Arguedasa, oraz rozdział 16: Udawać pisthaco. Formy ludyczne i ekspresje artystyczne.

Książka E. Jodłowskiej i M. Mąki jest jedną z najobszerniejszych, najbardziej wszechstronnych, wnikliwych prac o pishtaco jako symbolu chorób wyniszczających Peru od niemal pięciu wieków. Cennym jej aspektem jest to, że autorzy potraktowali zastane opracowania naukowe z szacunkiem („są godne uwagi”), 
choć z żadnym z nich nie zgodzili się w pełni, że własne interpretacje formułują ostrożnie (podkreślają to często) i w kategoriach prawdopodobieństwa, więc do dyskusji (takie badania „przynoszą więcej pytań niż odpowiedzi). Godne podkreślenia są ich umiejętności pisarskie, które podporządkowali umiejętnościom naukowym, konsekwentne i błyskotliwe stosowanie przyjętych metod oraz fakt, że schematy teorii naukowych nie osłabiły ich wrażliwości na historyczny i etnograficzny konkret. 